\title{
Critical Success Factors in Indian Commercial Banks
}

\author{
S.Lakshmi
}

\begin{abstract}
The important success factors to sustain strategically in the business environment of Indian Commercial Banks are found in the present study using Factor analysis. To remain competitive, stay customer-focused, imparting new, fast and technology-enabled services is possible only through critical success factors of Banking sector. A sample of 45 bank branches of public sector and private banks are studied through Bank executives and the success factors are found to be Employee Empowerment, Service Culture and Bank Evidence, Service Culture and Bank Evidence, Benchmarking Union involvement, Customer Satisfaction, values and ethics.
\end{abstract}

Key Words - Employee Empowerment, Benchmarking, Customer satisfaction, Service Culture Values and Ethics.

\section{INTRODUCTION:}

The term of CSF( critical success factors) was primarily introduced by Rockart (1979), to find the data needs of Chief Executive Officers as way of helping them define their decision making capabilities for managing their operations. He defined CSFs as key functional areas if satisfactory results are found, will ensure competitive advantage for the firm.

The industrial growth and technological development of the country mainly depends on economic development which in turn depends on banking sector. The banking industry plays central role to prosper and flourish the economic growth of the country. According to the reports, GDP (Gross Domestic product) rate will make Indian banking industry the third largest in the world by 2025 . The service industry itself accounts for more than $70 \%$ jobs and is likely to increase by $85 \%$.

The main variables of this industry, namely, total investments and loans have shown growth of 6.7 percent and 10.3 percent, respectively, as on $31^{\text {st }}$ March, 2018. The average GDP increase in banking and financial services as per CSO (Central Statistical Organisation) is estimated to increase from $7.3 \%$ in the fiscal year,2017, which is an increase from $6.7 \%$ during 2007, showing the improved productivity and development of this sector.The strategic factors which influences the quality service to the customers in Indian Commercial banks are of utmost important in the present juncture possible only through Quality management

\section{NEED FOR THE STUDY}

The banking sector is highest progressive industry in the service sector which helps all categories of people and hence proved to be a mass consumption service. It is evolved as high involvement industries.
Revised Manuscript Received on August 14, 2019.

Dr.S.Lakshmi, Assistant Professor in Management, S M S, SNIST, Ghatkesar, Rangareddy District-501301. (E-mail: glakshmi.s123@gmail.com) PH: 8106485540

\section{REVIEW OF LITERATURE:}

1. Dubey, Rameshwar et al., (2015) found that SRM and TQM on organizational environment are affected by the institutional pressures (IP) and leadership.

2. Irungu Kagwaini John(2014) concluded that commercial banks that align strategy to industry critical success factors are able to survive and gain a competitive advantage over other commercial banks. From the study, customer service, product range and pricing as well as adoption of ICT emerged as the most important critical success factors

3. Awolusi, Olawumi Dele (2013) showed that, for quality to be implemented, workers must be allowed to set goals and regular performance appraisal of the team, communication, top management commitment, mingling corporate strategy with Quality management, clear quality implementation vision, constant review of plans and budgets, effective process planning and controls, quality improvement methods and its measurement

4. Shivakumar B. Burli et al., (2012) found that high direct correlation between top people support, human resource management, process planning, never-ending improvement and performance of rice industries. This shows that top management must support vision and mission of the quality management . The company should focus on never-ending improvement in all the processes followed by organization. Process incremental improvements must be motivated and cross-functional teams must be formed to tackle and overcome the problems in the processes.

5. Talib F ., et.al (2012) conducted study which categorizes Quality Management in to four groups , quality of service, Technology based quality, On-line Quality of service,Banking Service product quality which are influencing the implementation of Quality service of the banking sector.

6. Cheng,Chun Hung et.al., (1996) found that factors that have contributed to the competition include globalization, technology advancments and dynamic government rules and policies. Quality management is a tool used by banks to have differential advantages that they are happy with the job they are doing. 


\section{OBJECTIVES OF THE STUDY:}

1. To study in detail the Critical Success factors through quality management variables in public and private banks.

2. To find the CSF influencing TQM practices in both the banks.

\section{RESEARCH METHODOLOGY:}

Sample size

As on 1-4-2012, there are nearly450 Public sector and Private sector bank branches in twin cities of Hyderabad and Secunderabad of Telangana State. From that $10 \%$ of bank branches are considered for the study i.e., nearly 45-50 bank branches are considered. Bank managers and Bank executives of minimum 2 years of experience of Total Quality Management (TQM) implemented banks is considered for the study. Here a sample of 181 from Public sector banks and a sample of 229 from Private sector banks, a total sample size of $410(=181+229)$ selected at random constituted the sample for the study.

\section{ANALYSIS OF DATA \& RESULTS}

The collected questionnaire from the respondents were examined for the competencies in all the matters and entered in data sheet with coding in the SPSS 19.0. Data were processed using the same statistical package.

\section{Principal Components Method}

TABLE 5.17: KMO and Bartlett's Test

\begin{tabular}{|l|l|l|}
\hline \multicolumn{2}{|l|}{ Measure of Sampling Adequacy. } & .946 \\
\hline \multirow{3}{*}{$\begin{array}{l}\text { Bartlett's Test of } \\
\text { Sphericity }\end{array}$} & $\begin{array}{l}\text { Approx. Chi- } \\
\text { Square }\end{array}$ & 24879.016 \\
\cline { 2 - 3 } & Df & 2701 \\
\cline { 2 - 3 } & Sig. & 0.000 \\
\hline
\end{tabular}

The Kaiser- Meyer -Olkin (KMO) test of sampling adequacy and Bartletts test of sphericity is applied for the data. A value of 0 indicates sum of partial correlations is large compared to sum of correlations indicating diffusion in the pattern of correlations. So, factor analysis is quite inappropriate. A value of 1 indicates pattern of correlations are relatively compact so factor analysis could yield reliable and distinct factors. Here the KMO statistic is 0.946 the factor analysis is more appropriate.

Bartlett's measure tests that null hypothesis of the original matrix is an identity matrix. There has to be some correlation between variables and if the R-matrix were an identity matrix then all the coefficient of correlation would be zero. So, we want this test to be significant. The test of sphericity is highly significant $(\mathrm{p}<0.001)$ and therefore factor analysis is the right choice. It extracts all the factors with eigen values more than 1 , which results in seven factors.

PCA (Principal Component Analysis) works on principle that all variance is common, so before extraction, the communalities is 1 . The $68.3 \%$ of the variance associated with the question 1.1 is common or shared variance. This output shows the component matrix before rotation. This matrix contains the loadings of each variable on to each factor. The loadings less than 0.4 are suppressed in the output and only those variables with more than 0.4 factor loading is considered for the study. SPSS has selected seven factors.

TABLE 2: Factor Analysis

\begin{tabular}{|l|l|l|}
\hline S.No & \multicolumn{1}{|c|}{ Variables Focussed } & \multicolumn{1}{|c|}{ New Factors } \\
\hline 1. & $\begin{array}{l}\text { Top Management inclination to allocation of resources, Better superior }- \\
\text { subordinate relationship, Commitment to Total Quality Management }\end{array}$ & $\begin{array}{l}\text { Employee } \\
\text { Empowerment } \\
\text { Service Culture and } \\
\text { Bank Evidence }\end{array}$ \\
\hline 2. & $\begin{array}{l}\text { Positive Impact of Physical environment, Branch location at convenient } \\
\text { places, Public Responsibility }\end{array}$ & $\begin{array}{l}\text { Human Relations } \\
\text { Intenice to Customers, Pleasing and Courteous behavior of employees, Depth of Service }\end{array}$ \\
\hline 3. & $\begin{array}{l}\text { Effective Correlation between Customer Satisfaction and Financial } \\
\text { Performance, Benchmarking on Services, process, Training programs } \\
\text { Customer focus and Human Resource Management }\end{array}$ & Benchmarking \\
\hline 5. & $\begin{array}{l}\text { Union Participation in Recruitment and Selection, Role of Union in Policy } \\
\text { Decision making }\end{array}$ & $\begin{array}{l}\text { Union Involvement } \\
\text { Sustomer }\end{array}$ \\
\hline 6 & \begin{tabular}{l} 
Customer focused and Continuous Improvement. \\
\hline 7
\end{tabular} & $\begin{array}{l}\text { Ethical code for Employee Selection, Training for team building and Group } \\
\text { Dynamics }\end{array}$ \\
\hline
\end{tabular}

\section{FINDINGS OF THE STUDY:}

Factor Analysis is a tool helps to know the factors to be extracted. If the number of units in the sample crosses 250 and the communality is greater than 0.6 then we have retain all the factors with Eigen values above 1 . 
1. Factor analysis helps to identify seven factors from twelve factors; new factors as suggested by factor analysis is the question that relies on factor 1 seem to all relate to empowering the employees toward Quality Management practices. Therefore we name this factor as 'Employee Empowerment'.

2. All the variables are related to physical evidence of the bank and service culture. Therefore we name this factor as 'Service culture \& Bank Evidence'.

3. The various variables on factor 3 related to soft aspect of service quality focusing mainly on customers. Therefore we can name it as 'Human Relations'.

4. The other variables, all related to benchmarking and statistical usage of data. Therefore we might label this factor as 'Benchmarking'. Here benchmarking on training programs, customer focus, human resource management, level of service capes are considered.

5. The variables are related to union involvement in recruitment and selection and policy decisions. Therefore we name it as 'Union Involvement'.

6. The variables that is loading on factor 6 relate to Customer focus on day-day basis and continuous improvement. Therefore we name them as 'Customer Satisfaction'.

7. The variables are work values, ethics, group dynamics and team building. Therefore we name it as 'Values \&Ethics'.

\section{LIMITATIONS:}

- The study is limited to only twin cities of Hyderabad and, Secunderabad of Telangana state.

- Only few banks are considered for the study. Other groups of banks under Indian commercial banks like foreign banks, regional rural banks cooperation banks etc., are ignored in the present study.

\section{RECOMMENDATIONS OF FUTURE RESEARCH:}

The study can be further enhanced by including more types of other banks. The study can further carried out in the other group of banks namely foreign banks. The present research study is limited to only twin cities, Hyderabad and Secunderabad of Telangana state. Some more new areas of Total Quality Management practices that can be focused are value-added and techno services to the customers.

\section{CONCLUSION:}

In the competitive banking industry, so many new banks are in the fray. The Critical Success factors through Total quality management practices are identified as Employee Empowerment, Service culture and Bank evidence, Human Relations, Benchmarking, Union Involvement, Customer Satisfaction and Values and Ethics. The new banks or any bank has to identify and concentrate on strategic factors so as to remain customerfocused, competitive and offer technology oriented innovative service for quality and speedy response to the banking customers.

\section{REFERENCES:}

1. Awolusi, Olawumi Dele.(2013).The Effects of Total Quality Management on Customer Service Management in the Nigerian Banking Industry: An Empirical Analysis, International Journal of Management and Network Economics, 2013, vol. 3, issue. 1, pp. 57-77.

2. Irungu Kagwaini John .(2014)., Alignment of strategy to industry critical success factors among commercial banks in Kenya., School of Business, University of Nairobi.

3. Rockart, J.F. (1979). "Chief Executives define their own data needs," Harvard business Review,Vol. 57 No.2 pp 8193.

4. Cheng Chun Hung, Madan Manu S. \& Motwani Jaideep.(1996). Implementing Quality Management in the Banking Sector, Total Quality Management,Vol.7 No.4 347-356.

5. Dubey, Rameshwar., Gunasekaran, Angappa.,\& Samar Ali, Sadia.(2015).Exploring the Relationship between Leadership, Operational Practices, Institutional Pressures and Environmental Performance: A Framework for Green Supply Chain , International Journal of Production Economics, v. 160, pp. 120-32.

6. Kothari.C.R., (2010). Research Methodology-Methods and Techniques Second revised edition, New Delhi, New Age International publishers.

7. Shivakumar B. Burli., B. B. Kotturshettar.,\&Ruchita V Dalmia. .(2012). Multiple Performance Measures: Six TQM Practices,SCMS Journal of Indian Management.

8. Talib F., \& Rahman Z.(2013). Current Health of Indian Healthcare and Hospitality Industries: A Demographic Study. International Journal of Business Research and Development. 2 (1) 1-17.

9. "Business Financing: Banks". Government of India Retrieved 12 January 2015.

10. "Directory of Bank Offices: Certain Concepts". Reserve Bank of India. Retrieved 12 January 2015.

11. Indian banking system. I.K. International Publishing House Pvt Ltd. 2006. ISBN 81-88237-88-4. 